\title{
Paradigm of Islamic Education in the Future: The Integration of Islamic Boarding School and Favorite School
}

\author{
St. Wardah Hanafie Das, Abdul Halik, Amaluddin \\ Muhammadiyah University of Parepare, Islamic College of State of Parepare, Indonesia \\ wardahhadas@gmail.com
}

\begin{abstract}
Islamic education goes into future options, and became a reference in developing the potential of learners and the embryo of world civilization; the progress of Islamic civilization was born of Islamic education quality. Therefore, islamic religious education should be managed professionally, based saintek and quality. Islamic educational system urgently reformulated in accordance with the dynamics of the times, the needs of the market, and based on local wisdom, thus bringing forth a superficial scientists clerics and scholars scientist. Methodology used in this research is qualitative research, this research works in Parepare city, with sample of excellent school and Pesantren Al-Badar. The result of study is the integration of the educational system, good educational system and system seed boarding school education, relevant done as an attempt to find the ideal model of islamic education and real in the era of globalization.
\end{abstract}

Keywords: Excellent school, Integrity, Model of Islamic education

\section{Introduction}

Contemporary educational system is dichotomized by the importance of profane and transcendence. Therefore, education out-put gets various problems to survive in the wrestling era. On the other hand, there is a modern out-put and traditional out-put. Consequently, the convergence discourse of Islamic educational system dichotomized is urgent to be reformulated (Baharuddin \& Sri, 2011). Historically, Islamic education in Indonesia which is still exist and consistent with cultural local is Islamic boarding school, yet in general, the weakness of it is lack of seeing the global knowledge in the future, Islamic boarding school is more strengthening or often called beyond education (Wakhuddin, 1998:207). Even though the appreciation of it is not necessarily corrected, yet this statement is able to be a "reflection" that Islamic boarding school is urgent to revival in answering the demand of the era. The discourse above is relevant and urgent to do introspection, reflection, prospection, and projection in formulating the Islamic educational system. The existence of Islamic education in the future is determined by integrating the ability culturally with the international system indicated with rational relation, dynamic and competitive (Mastuhu, 1999: 276). Islamic boarding school is faced by the acceleration of science and technology. Those are appropriately able to adapt and contribute the modern development. Besides, it has to maintain its own characterization as the basis of spiritual moral and its function in constructing the religious society. Islamic boarding school in the future is urgent to reformulate the system being the best choice in facing the globalization era. Accelerative change by the development of SAINTEK demands its adapting and contributing system. This change is appearing the combinations of Islamic morals, traditions, and developed cultures, so that the education will be integrative (Muchsin and Wahid, 2009: 70). Thus, the demand of collaboration of Islamic boarding school with favorite school is a choice on synergizing the advantage and reducing the weakness (Muhaimin, 2009: 105). Islamic boarding school is assessed as the basis of the religiosities and moral, then favorite school as the basis of science result and managerial. Synergistic of both educational systems is able to be an alternative of Islamic educational system connected with dynamic and the demand of the era.

\section{Literature Review}

Islamic Educational system in Islamic boarding school: Islamic boarding school is educational institution which is based on the Islamic principle. It is being a unique characteristic of Islamic education in Indonesia which it is based on the grass root societies. The Islamic institution has factually existed in over century. It is an indigenous education, then it got a modification of its educational system/mosque, curriculum, technique, teaching method, etc (Azra, 1998:91). Islamic boarding school got transformation and adaptation with the 
cultural local wisdom of archipelago and Islamic morals. The advantage of it is based on both integration and synergy of morals power. In this case, Islamic boarding school, as the community and the biggest educational institution, has given an asset in creating the religious human (Tafsir, 2000:191). The institution has produced a lot of leaders in the past, present, and the future. Most of the graduated students of Islamic boarding school took participation in developing nation. We can see the mission of 'Islamic boarding school' as a big asset on producing religious generation and developing nation. It is because of the central orientation of Islamic boarding school is learning creed (Tafsir, 2000: 230).

Zuhri (2002: 51) defines Islamic boarding school is a system of tafaqquh fi ad-din which is usually backing up by some components either software nor hardware supporting the existence of Islamic boarding school as a system such as kiyai, santri, tradition of reciting the holy qur'an, guardian's home, mosque, and the classroom placed for staying in Islamic boarding school. As the institution of tafaqquh fi ad-din, this function to keep, develop, report, and conserve the Islamic religion, and of course it wants to produce Islamic religious teachers. It is the same as what Prasojo said (1982:2) that Islamic boarding school is an educational institutions and teaching of the Islamic religion generally using non classical method which Ulama teaches Islamic knowledge to santri based on the verse written by using Arabic language or Ulama in the middle century, and santri are usually staying in the Islamic cottage. The uniqueness of Islamic boarding school as the Islamic institution is still exist in giving Islamic values to the societies with model, strategy, and individual approach. Buchori (1994: 3) reminds that Islamic boarding school is a part of internal structure of Islamic education in Indonesia conducted traditionally, Islam as the way of living. The life style in Islamic boarding school seems different with the environment such as simplicity life, leadership charisma, santri's obedient, diligence of understanding the classical verse, togetherness, sincerity, etc. Islamic boarding school ratify the values of Islam through the local wisdom, and being a media synergizing both of norms which is culturally assessed very near and identical.

On the other than, Abdullah (1995: 3) describes that in every varieties, Islamic boarding school is a seedbed, experience, and also spreading the Islamic knowledge. This looks at the prototype of Islamic boarding school as educational and proselytizing institution. Next, Dhofier wrote that; cottage, mosque, santri, reciting the classical verse, and kiyai are five basic components of Islamic boarding school tradition, then she continued her theory that a reciting institution that has developed until it has those five elements, its status will change as the Islamic boarding school (Dhofier, 1990: 44). In scientific context, the existence of Islamic boarding school is realization of egalitarisme of Islam in scientific and human field. Because of it, every single Muslim having the knowledge, religious knowledge in certain aspect, is seen having the sacred aura (Azra, 1998: 88). This thing is clarification of three main functions, those are; transmission of Islamic tradition, maintenance of Islamic tradition, and candidates of ulama. Those three main functions above show the consistency at the Islamic pattern of Islamic boarding school.

Imam Bawani described the characteristic in the system and his philosophy. Those characteristics are:

a. Philosophy of Islamic boarding school is traditionally characterizing ahlu sunnah wal jamaah;

b. Islamic boarding school curriculum is only about Islamic knowledge;

c. Using a classical teaching method;

d. Simplistic and classical facilities;

e. The environment of Islamic boarding school is mostly in the village;

f. The relation between kiyai and santri forming intellectual geology and kinship (Bawani, 1993:108).

The identity of Islamic boarding school is the place and ideology fort of Islam from the intervention and contamination of imperialism. It is not only used to represent the tradition of Islamic education but also being a symbol of the Islamic local tradition. The identity of it is as the collaboration of Islamic substance and the local wisdom being a unique treasure in education. It is a symbol of the education unit integrating Islam and the local wisdom which are factually intellectual, emotional, spiritual, and social development. The purpose and orientation of it is being a modal to survive and exist in the globalization era. Islamic boarding school built in the educational system combined by history of archipelago. It has produced some good souls to ascertain the standardization of morals. These souls will be the characters which never be built by others educational system as a whole. Islamic boarding school's soul implicates in five souls: 
a. Sincerity

b. Simplicity but prominent

c. Ukhuwah Islamiyah which is Democratic

d. Independent

e. Free to choose alternative way of life and decide the ambition seriously and optimistically to face problems of life based on Islamic morals (Siradj, 1999: 216).

Soul or Spirit of character which is built by Islamic boarding school implicating with the learning attitude and diversifying. The attitude of studying can construct the santri because of concern and togetherness constructed in their community. It is also happening in the attitude of diversity which is being powerful and stable because they are remaining each other and using this tradition in their daily life collectively and collegially. Sincerity, obedience, patience, and giving thanks to Allah are being a requirement of life and studying in Islamic boarding school. Those things are being a factor of santri to be excited in doing worship, studying Islam, and living in the simplicity. Living in the Islamic boarding school gives advantages such as interaction between teacher and students intensively, controlling the student easier, giving simulation or stimulus of studying, and giving a good chance at the habitual. Learning system in the Islamic boarding school is generally traditional and nontraditional. Traditional method is offering with balahan, weton, sorogan, and nontraditional is the new method introduced to the institution based on the scientific research (Arifin, 2000: 209). There is an awkward thing inside of Islamic boarding school in maintaining its traditional method has been happening in the hereditary. Besides, methods are seldom to get sympathy. Furthermore, it is sometimes doubted by members of Islamic boarding school, whether it is influenced by introvert and extrovert leader in order to show, use, and produce the new methods needed to do the wise approaches for teachers in the Islamic boarding school (Rizkiani, 2012: 12).

In consequence, it is impossible to combine the curriculum among Islamic Boarding Schools when there are still big differences inside of educational system used in. This appears in the Islamic boarding school. Generally, it is not formulating the goal of education specifically elaborated in the complete and consistent system of education (Nata, 2001:167). Yet in general, the goal written in Ta'lim al-mua' allims' book created by Zarnuji (1963). Several moral guidance of Islamic boarding school is improving knowledge because of obligation honestly. On the other hand, religion studied is a basic moral bringing the education goal, creating a good human of having an Islamic awareness that Islam is comprehensive weltanschauung (Madjid, 1997: 18). In order to conduct the goal, it is needed to celebrate reciting the holy Qur'an which has a basic moral of Islam. Amount of book decided to be studied in Islamic boarding school is seen as its curriculum. Understanding the curriculum is same with the perspective of Nata, "Amount of subjects obligated to be passed in getting a particular educational certificate (Nata, 1997: 123), while Islamic boarding school curriculum is containing eight subjects, namely humaniora knowledge (Kuntowijoyo, 1994: 20).

Islamic boarding school's subjects contain Arabic language (tool science), fiqh-ushul, tafsir, hadist, adab (Arabic literature), attitude, tasawuf and tarikh (Dhofier, 1990: 20). Series of those subjects exist in every single book level which is containing two visions of education, those are; first is moral vision, it is teaching the attitude and akhlakul karimah, second is intellectual vision, it is improving the ability of thinking (Nata, 1997: 168). In several Islamic boarding schools, the implementation of educational system and teaching got the transformation because of the influence from science, technology, education in Indonesia, and the demand of the societies in the Islamic boarding school itself. Then, some of Islamic boarding schools are still maintaining their own old system. In this case, Ghazaly (2000: 32) defined teaching method in Islamic boarding school consists of two systems, those are:

a. Traditional system:

1) Sorongan, is the educational system which every santri is reciting Qur'an in front of Ustadz and Kiyai.

2) Wetonan, is educational system which Kyai reciting Qur'an to the santri, then it is followed and seen by santri.

3) Bandongan, is the combination of two methods above.

b. Modern system:

1) Classical system

2) Course system

3) Training system 
The classification of Islamic boarding school is a reflection on responding the dynamic of era and dialectic of science and technology acceleration. Accommodative and rejection toward the dynamic is ijtihad of the leader of Islamic boarding school regarding the ways that should be passed in order to develop the educational institution. One unique thing that it is still maintaining is expanding the characters through Islamic education culture in the Islamic boarding school's environment. In fact, the implementation of educational system and teaching at the Islamic boarding school is now classified in three forms:

a. It is an educational institution and Islamic teaching generally given classically which the kiyai teaches santri-santri based on Arabic verse or familiar ulama since in the middle era, while every santri is usually staying in the cottage or dormitory of Islamic boarding school.

b. It is the educational system and Islamic teaching basically similar with the Islamic boarding school above, yet every santri has no provide a cottage, but they lives in resident around it.

c. Nowadays, it is the group institution between Cottage and Islamic School giving education and Islamic teaching by using bandongan, sorongan, and wetonan system. Every santri is provided a cottage or even santri kalongan which in modern education term fulfilled the criteria of the informal education, and also celebrate the formal education like madrasah until favorite school in every grade and various department based on their interest (Department Agama RI, 1985: 10).

Thus, the system of Islamic boarding school can be seen into three forms. First, there is Islamic boarding school which is complete with cottage and educational system for 24 hours, second is Islamic boarding school which has no cottage and educational system is only for particular times, and last is Modern Islamic boarding school which santri lives in the cottage and it has general subjects. The discourse of Islamic boarding school in applying good ideas, that educational system sees the Islamic educational system combining the deductive normative approach of Islamic values: Al-Qur'an, As-Sunnah, and law of Allah in the universe with descriptiveinductive approach that can preserve human aspiration and develop the culture based on the goal of independence by using a formulation of education program based on the output oriented (Faisal, 1995: 116). Global character in education of Islamic boarding school is very famous with vis a vis between power and weakness of Islamic education which comes from society and sometimes being orthodoxy, so that the management of Islamic education should dominate the four domain priorities, those are:

a. Quality development.

b. Innovation and creativity development.

c. Networking the corporation.

d. The realization of regional autonomy (Tilaar, 2000: 153).

In realization process of education, it is very influenced by the system of constructing the education. So in Islamic educational system, it can be seen with manifestation of Islamic morals and its learning is filled by Islamic education. The tendency of the contemporary Islam is massive effort at the scientific Islam in order to implement the influence of secularization and reduce the dichotomy of educational system. That awareness gives wish to the Islamic education development so that it can be survival in the wrestling civilization. This shows the indicator that Islamic education is an alternative way of the education development in the future. In the education management, Islamic boarding school is oriented to the talent, competence and skill, logic, critical, rational analysis and spiritual development by looking for abstract meanings in order to illuminate the living. In traditional Islamic boarding school, its education management is still filled by charisma and authority factor of kyai. Consequently, policy is still top down. It is an instructional policy of kyai. Besides, the modern Islamic boarding school has been shifting its management pattern. Simply, it has implemented the participative management. Participative management is one of the fundament indicators based on the school (MBS). MBS is a school management model which is very relevant with the educational autonomy, based on the circumstance of democratic societies (Suryosubroto, 2004; 31). The development of the society is stimulated by the acceleration of science and technology producing many demands and very complex needs. This has brought influence to the existence of Islamic boarding school in doing education process. It seems there are various models and educational system in responding the dynamic era, yet in general, it can be classified into two patterns, those are: Traditional pattern which is still consistent on the system and learning program by taking a few of general lesson, and the modern pattern combining the characteristic of Islamic boarding school (system and its learning program) and the characteristic of Public school containing science and technology. The collaboration of both approaches is being one of the forms of contemporary Islamic boarding school showing its own uniqueness and attractiveness. 
Educational system in Favorite School: Indonesia is one of the countries which are in the low rating of quality of education in the world. Based on the yearly report of UNESCO Education for All Global Monitoring Report 2012, quality of education in Indonesia is on 64 of 120 countries in all around the world. This reality makes Indonesian worried which the quality of education is still anxious. It is far from the rating of Singapore and Malaysia. On the other hand, another realities portrays the quality of education especially of the Indonesian's students is getting achievement and award at the International event whether at the Physics, Mathematics, and Robot Olympiad. Those portray that the quality of education in Indonesia can compete in the international level, but it has not been equal in Indonesia as a whole. The implementation of Undangundang No.20 Year 2003 about National educational system is putting school as a part of subsystem of national education. School as the instrument to develop the innovation and discovery whether it is institutionally or even from its quality of out-put (Muhaimin, 2009: 35). The quality of school output has been determined in UUD 1945 pasal 31 ayat 3 which is saying that the government effort and accomplish a national educational system improving creed, virtue, and ethics. This context emphasizes that education in the school level is guided to be a part of excellence to produce the intelligence, emotional, spiritual, and good vocational. The integration of the intelligence is relevant and urgent to be developed through education in the school as the form of penetration and up to date innovation in order to facilitate the appearance of good output.

The societies put their hope to the favorite school to educate the innovative and competitive generations. The favorite school got the trust from societies to entrust their children without thinking how much the payment will be spent. This reality makes the favorite school being a good business out of the particular mission of school built by the private. Favorite school implements the modern management giving a guarantee of the quality and leaning process of education. Therefore, the society is able to control and evaluate activities in the school. The societies' mindset is more trust at the vision, mission, goal, and reliable programs and getting the warranty of quality. Ontologically, the perspective of ministry of education at the favorite school is school developed to achieve the favorite output. In achieving the superiority, it needs input, learning process, teacher, educators, management, educational service, and facility to support the goal (Muhaimin, 2009: 39). This perspective describes the favorite school which has output indicators, process, supra structure, and infrastructure.

The indicators of favorite school portraying in the effective prototype of school. The criteria of effective school, based on Danim (2006: 62), can be seen as follows:

a. Improving the standardization of working and clear about the goal of students to know and work for something.

b. Stimulate the activity, multi cultural understanding, gender equality, and improving the learning process based on the potency standard had by the students.

c. Expectancy of students to take the responsibility in studying and behavior.

d. Having an instrument of evaluation and assessment of students' achievement regarding students' capability, deciding the meaningful feedback for students, family, staff, and educational environment.

e. Using the learning method based on educational research and voice of professional practice.

f. Organizing school and class to create the environment supporting the learning process.

g. Making the democratic decision and accountability for students' success and satisfaction of user.

$h$. Creating the comfortable, respect, and accommodate the environment effectively.

i. Having the high wishes to all staffs to improve their capability in terms of professionalism and capability of practice.

j. Putting the family in helping students to achieve their success actively.

k. Cooperating with societies and other people to support students and their family.

Those criteria above portray the circumstance of the favorite school. Favorite school is created because it is managed by professional human resource, so that education process is running well and similar with the demands of era. Various things appearing in the favorite school is the excellent of academic service, based on the technology, educative environment, democratic management, participative management, partnership relation with societies, etc. The circumstance inside of school will give a good achievement compared with others school. The effective of School manager implicates on the process and result of the good education. The system of favorite school shows the programs and activities effectively, especially in education activities of 
learning process. The more effective school's program, the more applicable the organization of favorite school will be. The characterizations of effective school are:

a. Climate and School's culture;

b. The higher wishes to get achievement;

c. The observation toward the improvement of students;

d. The leadership of headmaster;

e. The involvement of parents in school's activities;

f. Freedom, responsibility, and involvement of students in the school.

g. The reward and incentive, and

h. The implementation of curriculum (Arismunandar, 2005: 65).

The model of favorite school wished in the future is the good leadership of headmaster, partnership with the stakeholder, the invention of academic culture and scientific, future orientation, democratic circumstances in the school. The model of favorite school is an ideal thing and it is needed commitment and togetherness to achieve the target. Jarome S. Arcaro explains that model of favorite school should be supported by five pillars, those are (1) focusing on the users; (2) the involvement of all members as a whole; (3) doing measurement, (4) commitment on the change; and (5) completing it continuously (Danim, 2006: 13). School orientating with five pillars above will stimulate the process of dialectic to be good achievement. Knowing the target that will be achieved, empowering teachers professionally, utilizing facilities maximally, doing evaluation continuously, and being consistent on the change and always organize the system, will increase the change dramatically based on the dramatic era. Then, the characteristics of favorite school are:

a. Focusing on costumer, whether to the internal or even external stakeholder;

b. The total involvement, every people should participate in participation of mute;

c. Measurement, measuring the affectivity of effort in fulfilling the standard;

d. Commitment, every supervisor and school board must have commitment on the mute;

e. The continue revision, repairing process continuously and make the necessary revision (Arcaro, 2007: 4).

In management perspective of mute at the education unit, school categorized as the favorite school should enclose these three aspects; those are suggestion to school which new students are being a target of school. Domain of intelligence quotient, emotional, and spiritual of candidate students ought to be on the selection test. Consequently, the selection test of new students should measure those three aspects of intelligence or even measure multi intelligence. The goal of test is to know the level of students' intelligence. This data of the students' intelligence can be used as a standard to determine their guiding process or even determine the target or education direction in the future (Trimantara, 2007; 7). In designing the favorite school, it should be described by input, process, output, outcome, and benefit impact way. The school's conceptions (The formal institution of education) are to care for the reproduction, awareness, and mediation simultaneously. Those school's functions are collected by education and learning process as a core business. School's main stream can be favorite if it has good systems whether its superstructure and satisfying infrastructure. Like in education components, favorite school, even from its learning program, curriculum, students, teachers, facilities, funding, the good relationship among societies. Thus, favorite school can be seen from infrastructure, funding, and the satisfying of its human resources. So that, in implementing the education and teaching process, those are necessary to create the good process which at the end it produces good outputs.

\section{Methodology}

The method of this research is qualitative research, this research work in Parepare city, with sample excellent school SMAN 5 Parepare and Madrasah Aliyah Pondok Pesantren Al- Badar. The characteristic of this research is comparative study, the second unit education with take overbalance system education and learning. Overbalance the second unit education with integration and formula of construction educational system is relevant with social dynamic and acceleration science. Energy source is headmaster, document of teacher, triangulation and focus group discussion for getting expert judgment education field. 


\section{Results and Disscussion}

The Reformulation of Islamic Educational system in the Future: Graduated students in the future are facing several of awful obstacle, those are global acceleration implicating on the competitive, individualism, secularism, materialism, etc. In facing those obstacles, school, as the place to develop potency of students, is demanded to prepare graduated students who can perform and survive in the globalization era. Those descriptions are expected to create good human. The indicator of good human is the person who realize about science, technology, creativity and morals are having the best role in facing the globalization era (Nizar and Syaifuddin, 2010: 89). Human's visions in the future are always orienting on utilizing and empowering science and technology followed by creativity, innovation, strong characters and human solidarity. Based on the phenomena and the demand of globalization era, therefore it is needed the development of quality of good education. Umar Juoro assesses that it is urgent to anticipate the change of competition decided by the quality of human resource and the ability of technology (Juoro, 1996: 168). The quality of education can be seen by its indicator which it can produce graduated students having the competitive human resource and be able to use technology.

The role of education is preparing individual and society; therefore, they have ability and motivation and participate actively on articulation and institutionalization of civilized society. Education has to be able to produce good human intellectually, morally, master on science and technology, and having a high commitment in every social pattern. At the micro level, the democratic education is needed decentralization and pluralism orientation. All these are reflecting on equity and accessibility of education chance (Nizar \& Syaifuddin, 2010: 92). The paradigms of Islamic educational system are developing the Islamic education by using multidisciplinary and interdisciplinary approach. Multidisciplinary approach is a form of the development of scientific knowledge in every single aspect, and interdisciplinary approach is intensifying the scientific knowledge in one cluster. The deepness and wideness of scientific knowledge can be realized to face the era, market, and the demand of scientific dynamics. The paradigms of Islamic education have to be established with strong foundation, scientific and based on the local wisdom.

Islamic boarding school as the educational institution is still istiqamah and consistent in doing its role as the central of intensifying the Islamic knowledge (tafaqquh fiddin), Islamic proselytizing institution, and participating to educate Indonesian which has been trusted by the society (Nizar \& Muhammad, 2010: 191). Islamic boarding school is on the domain of Islamic science development as the basis of characters affirming of students in giving contribution to develop the country. Then, public school is very important to develop the intelligent quotient, science and technology as the modals of competitive era. Therefore, the paradigm of developing the education unit in the future is synergist and collaboration of educational system of Islamic boarding school and public school, which those are more popular with boarding school. Boarding school is model of educational system integrating Islamic boarding school and public school's system. The combination of those education models is being an ancestor of the appearance of the new Islamic education which is representing Islamic, scientific and technologic tradition. The graduated students are wished getting the good provisions and global knowledge.

The steps of straightening above have to consider at least six things:

a. The goal of education in the future is need to fulfill the willingness, wish, and needs in the future.

b. The goal of global education is need to be guided on improving the technology and information.

c. The goal of global education has to be guided on economic problem understanding, language politic and global culture.

d. The goal of global knowledge is appropriate to be guided in the tight competition in every aspect among nations.

e. The goal of global education has to be guided on mastering language, so that it can be active in the international life.

f. The goal of global education especially on economic sector, business, and monetary need to be guided to achieve the affectivity and efficiency of production tools and service globally and competitively in the era of free market (Bastian, 2002: 62). 
The education of global orientation is ideal vision. It is because of being adaptive and accommodative toward the social condition and able to answer the phenomena by using the proportional ideas. Through this education, there are therefore eight preparations to face the future, those are:

a. Potential reading toward life they faced in.

b. Potential answer toward problems that appear.

c. Individual integration (abolishing the split of personality).

d. The ability of spreading the Islamic mission.

e. Perceptional integration (abolishing the dichotomy of perception).

f. Cosmopolitan integration.

g. The ability of keeping the nature.

h. Science input, technology and methodology (Getteng, 1997: 6)

Therefore, favorite school in perspective of Islamic education as a shoulder strap of glorious morals is:

a. Islamic education as one of cultural power is history, religious, and moral value.

b. Balancer and secular education is containing futuristic values and observer of glorious values.

c. Islamic education is containing the alternative education by proposing the democratic and independence value (Tilaar, 2002: 80).

Islamic education is assessed as the solution for human development as a whole, because its graduate students are directed to the faithful personal establishing and able to care for khalifah in the profound dogmatically. It should be established from collaboration of two characteristics of education model, namely Islamic boarding school and Favorite school. Islamic boarding school as a place to create religious values and students' morality as the basis of spiritual and emotional quotient (SEQ), and favorite school as a place to develop science and technology as the basis of intellectual and vocational quotient (IVQ). Students should be collected at the complex of education unit so that they can study for 24 hours (boarding school), the habitual of akhlakul karimah (character) are being more effective, improving the mindset and better vision in the future. Model of Islamic education unit is accommodating the ability of leadership, managerial, and administrative system in the favorite school to complete the attitude and leadership character which are charismatic and respected in the Islamic boarding school. The curriculum being united (Islam, Science, and Technology) will give solution of the superior generation establishment and having civility. Cultural research in the favorite school gives a positive value of scientific tradition in Islamic boarding school, so that it will be more adaptive and functional of Islamic science with the social life dynamic and technology. The description of future school of Islam is being an ancestor of the appearance of Islamic civilization in the globalization era.

\section{Conclusion}

Islam as a universal religion and related in every single aspect which is familiar with dogma Islam rahmatan lil alamin. As the religious civilization, Islam has to survive through the relevant system of education with progression era. The history in Indonesia, education unit as an icon of Islam is Islamic boarding school is assessed as the representation of Islamic science, while it has to interact with sciences acceleration and technology as the effort of the implementation rahmatan lil alamin. Consequently, favorite school as the science and technology representation are along with modern education are urgent to integrate with the system of traditional Islamic boarding school in order to give a better solution of achieving the goal of Islam. The solution is Islamic boarding school system is still maintained at the academic cultural aspect which propose creativity. Community aspect at the area of ushuliyah religion and akhlakul karimah, and then creativity aspect is at the rationalization area and research. The collaboration peculiarities of educational system is being model of Islamic education which has prospect and able to answer the demand of era.

Acknowledgements: Our Thanks to Dr. Syarifuddin Yusuf, M.Si. as the rector of Muhammadiyah University of Parepare who helped the foundation during this research and publication in $10^{\text {th }}$ International Conference on Education and Information Management (ICEIM) Agro Wisata Hotel, Palopo, Makassar, Indonesia December 23, 2015. 


\section{References}

Abdullah, A. (1995). Falsafah on Kalam in Era Post Modernisme. Yogyakarta: Pustaka Pelajar Publishing.

Arcaro, J. S. (2007). Quality in Education: An Implementation handbook. Yogyakarta: Pustaka Pelajar Publishing.

Arifin, H. M. (2000). Capita Selecta in General and Islamic Education. Jakarta: Bumi Aksara Publishing.

Arismunandar. (2005). Education Management: Opportunity and Threat. Makassar: Universitas Negeri Makasar Publishing.

Azra, A. (1998). Moslem Intellectual Essay and Islamic Education. Jakarta: Logos Wacana Ilmu Publishing.

Baharuddin, U. \& Sri, M. (2011). Educational Islam in Dichotomy: Historicity and the implications on the Islamic Society. Bandung: Remaja Rosdakarya. Publishing.

Bastian, A. R. (2002). Education Reformation: Steps Renewal and Empowerment Education in the Context of Decentralization Education System in Indonesia. Yogyakarta: Lappera Pustaka Utama Publishing.

Bawani, I. (1993). Tradisionalisme in Islamic Education. Surabaya: Al-Ikhlas Publishing..

Buchori, M. (1994). Educational Study and Educational Practice. Jakarta: IKIP Muhammadiyah Jakarta Press, Publishing.

Danim, S. (2006). New Vision School Management: Unit Bureaucracy to Academic Institutions. Jakarta: Bumi Aksara. Publishing.

Department of Religion on Republic of Indonesia. (1985). Guidelines Boarding School. Jakarta: Dirjen, Bimbaga Islam. Publishing.

Dhofier, Z. (1990). Pesantren of Tradition: Worldview Studies of Kyai. Jakarta: LP3ES. Publishing.

Faisal, Y. E. (1995). Reorientation of Islamic Education. Jakarta: Gema Insani Press. Publishing.

Getteng, A. R. (1997). The Moral Development In the Islamic Education: Youth, Women, Development. Makassar: Yayasan Al-Ahkam. Publishing.

Ghazaly, B. (2000). The Pesantren of Educational is Based Environmental. Jakarta: IKAPI. Publishing.

Juoro, U. (1996). Human Resource Development and Technology in Support of Industrialization and National Competitiveness, in Seize the Future. Jakarta: Amanah Putra Nusantara. Publishing.

Kuntowijoyo. (1994). Historical Dynamics of Indonesian Muslims. Yogyakarta: Pustaka Pelajar. Publishing.

Madjid, N. (1997). Cubicles Pesantren: A Journey Images. Jakarta: Paramadina. Publishing.

Mastuhu. (1999). Empowering the Islamic Education System. Jakarta: Logos. Publishing.

Muchsin, H. B. \& Wahid, H. A. (2009). Contemporary of The Islamic Education. Bandung: PT. Refika Aditama. Publishing.

Muhaimin. (2009). The Islamic Education of Paradigm: From Paradigm Development, Institutional Management, Curriculum to Learning Strategy. Jakarta: Rajawali Press. Publishing.

Nata, A. (1997). Philosophy of Islamic Education. Jakarta: Logos. Publishing.

Nata, A. (2001). History of Growth and Development of Institutions of Islamic Education in Indonesia. Jakarta: Grasindo \& IAIN Jakarta. Publishing.

Nizar, H. S. \& Syaifuddin, M. (2010). Contemporary issues of Islamic Education. Jakarta: Kalam Mulia. Publishing.

Prasojo, S. (1982). Boarding School Profile. Jakarta: LP3ES. Publishing.

Rizkiani, A. (2012). Effect of Character Formation Against Boarding School Students: Research in Ma'had Darul Arqam Muhammadiyah in Garut. Journal of Education University of Garut, 06(01).

Siradj, S. A. (1999). The Pesantren Future: Empowerment and Transformation Discourse. Bandung: Pustaka Hidayah. Publishing.

Suryosubroto, B. (2004). Education Management in School. Jakarta: Rineka Cipta. Publishing.

Tafsir, A. (2000). Educational Study in Islamic Perspective. Bandung: Remaja Rosdakarya. Publishing.

Tilaar, H. A. R. (2000). New Paradigm of Islamic Education. Jakarta: Rineka Cipta. Publishing.

Tilaar, H. A. R. (2002). Fixing the National Education of Indonesian. Jakarta: Rineka Cipta. Publishing.

Trimantara, P. (2007). Superior Schools: Between Reality and Dreams. Journal of Educational Sower, 08(6), Publishing.

Wakhuddin. (1998). Tarmizi Taher: Bridges People, Ulama and Umara. Bandung: Granesia, Publishing.

Zarnuji. (1963). Ta'lim al Muta'allim. Kudus: Menara

Zuhri, S. (2002). The Pesantren of Curriculum Reformulation, in Ismail SM, Nurul Huda, and Abdul Khalik (editors). Dynamics of Pesantren and Madrasah. Yogyakarta: IAIN Walisongo Semarang \& Pustaka Yogya, Publishing. 